Published in final edited form as:

Biochemistry. 2020 June 09; 59(22): 2111-2119. doi:10.1021/acs.biochem.0c00290.

\title{
Effects of Nucleobase Amino Acids on the Binding of Rob to Its Promoter DNA: Differential Alteration of DNA Affinity and Phenotype
}

\author{
Chao Zhang, \\ Biodesign Center for BioEnergetics, Arizona State University, Tempe, Arizona 85287, United \\ States \\ Shengxi Chen, \\ Biodesign Center for BioEnergetics, Arizona State University, Tempe, Arizona 85287, United \\ States;
}

Larisa M. Dedkova,

Biodesign Center for BioEnergetics, Arizona State University, Tempe, Arizona 85287, United States;

\section{Sidney M. Hecht}

Biodesign Center for BioEnergetics and School of Molecular Sciences, Arizona State University, Tempe, Arizona 85287, United States;

\begin{abstract}
Nucleic acid binding proteins have been studied extensively, but the nature of the interactions that control their affinity, selectivity, and DNA and RNA functions is still not well understood. To understand the nature and functional consequences of such interactions, we introduced nucleobase amino acids at specific positions of the transcriptional regulator Rob protein in vivo and succeeded in demonstrating that an alteration of the protein-DNA affinity can affect specific phenotypes associated with Rob protein-DNA interactions. Previously, we inserted different nucleobase amino acids in lieu of Arg40; this residue is known (via X-ray crystallography) to interact with the micF DNA promoter A-box residue Gua6. The interactions predominantly involved Watson-Crick-like $\mathrm{H}$ bonding. The present study focused primarily on the micFDNA promoter B-box; the crystallographically determined interaction involves $\mathrm{H}$ bonding between the agmatine moiety of Arg90 within an HTH motif of Rob and a phosphate oxygen anion to the $5^{\prime}$-side of Thy14. We had two main goals, the first of which was to demonstrate enhanced Rob-binding to the micF
\end{abstract}

Corresponding Authors: Larisa M. Dedkova - Biodesign Center for BioEnergetics, Arizona State University, Tempe, Arizona 85287, United States; larisa.dedkova@ asu.edu, Sidney M. Hecht - Biodesign Center for BioEnergetics and School of Molecular Sciences, Arizona State University, Tempe, Arizona 85287, United States; sid.hecht@ asu.edu.

Complete contact information is available at: https://pubs.acs.org/10.1021/acs.biochem.0c00290

Supporting Information

The Supporting Information is available free of charge at https://pubs.acs.org/doi/10.1021/acs.biochem.0c00290.

Tables of the experimental yields, figures regarding the reactions, and experimental methods for preparing and studying proteins with nucleobase amino acids (PDF)

Accession Codes

UniProtKB: E. coli Rob, P0AC10

The authors declare no competing financial interest. 
promoter DNA and the functional consequences resulting from the interaction of micFDNA with Rob analogues containing Arg90 nucleobase mimics. The second was to explore the possible functional consequences of enhancing the protein-DNA affinity with nucleobase replacements, which mechanistically mediate interactions differently than those reported to be operative for specific protein-DNA interactions. Nucleobase replacement at position 90 with Arg isosteres enhanced the Rob protein-micFDNA affinity in parallel with increasing antibiotic and $\mathrm{Hg}^{2+}$ resistance, while aromatic amino acid replacements increased the affinity but not the antibiotic or $\mathrm{Hg}^{2+}$ resistance. The demonstration of an increased affinity through strong base stacking interactions was notable.

\section{Graphical Abstract}

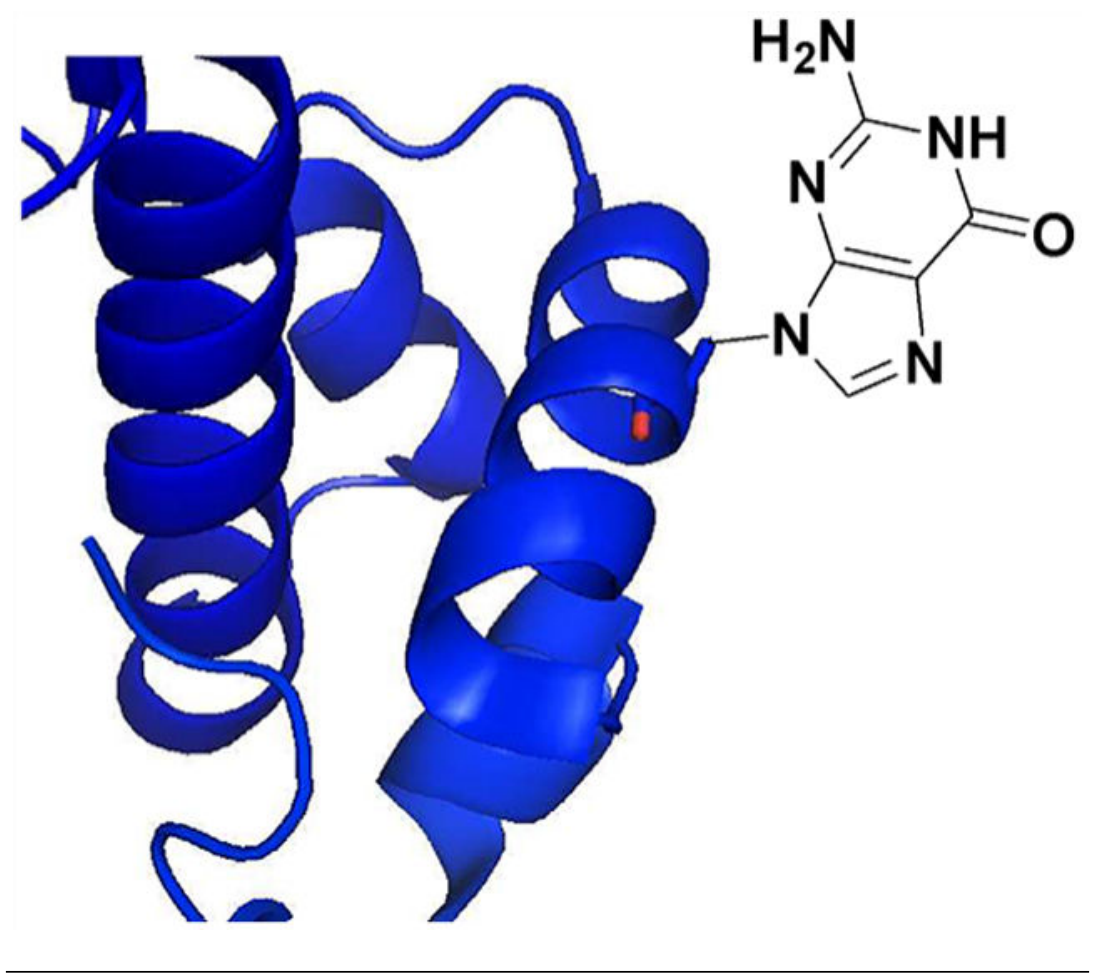

A non-coding RNA stress response gene found in Escherichia coli and related bacteria, micF, post-transcriptionally controls the expression of the outer membrane porin gene $o m p F .^{1-3}$ The micF gene encodes a non-translated 93 nucleotide anti-sense RNA that binds its target $o m p F \mathrm{mRNA}$ and regulates $\mathrm{OmpF}$ expression by inhibiting translation and inducing mRNA degradation. The $о m p F$ and $о m p C$ genes are regulated by the OmpR-EnvZ two-component signal transduction system. ${ }^{4-6}$ These genes are responsible for synthesizing their corresponding porins, which associate as homotrimers in the outer cell membrane and form pores that enable small hydrophilic molecules to enter cells by simple cross-membrane diffusion. ${ }^{7}$ Reducing the level of OmpF porin has been shown to result in bacterial multidrug resistance. ${ }^{4,7,8}$ The expression of MicF is controlled both by environmental and internal stress factors, and increasing MicF concentration decreases the cellular OmpF level. ${ }^{9}$ The micF gene has a complex promoter region that contains binding sites for several transcriptional regulators belonging to the AraC/XylS family. ${ }^{10,11}$ The best known are 
MarA, SoxS, and Rob. ${ }^{12-14}$ Rob has been proposed as a general transcriptional cofactor; ${ }^{15}$ in a rob deletion strain, but not in SoxS or MarA, the expression of MicF is not activated by cationic peptide antibiotics. ${ }^{16}$ There is some evidence that MarA can repress the rob gene through steric hindrance. ${ }^{17}$

The X-ray crystal structure of Rob bound to the micF promoter has previously been determined. ${ }^{18}$ The Rob protein consists of two domains. The N-terminus is homologous with transcriptional regulator MarA. ${ }^{19}$ This domain contains two helix-turn-helix (HTH) motifs that are connected by a rigid central helix that fixes their relative orientation and is responsible for DNA binding. The C-terminal domain (CTD) is unique to Rob and is not yet well understood. Recently, it has been suggested that the CTD regulates the activity of Rob and protects it from degradation by Lon protease. ${ }^{20}$

Rob, SoxS, and MarA have similar mechanisms of DNA binding. They all bind to an asymmetric DNA sequence $\sim 20$ base pairs in length, which is part of the gene promoter region. ${ }^{11,21,22}$ These binding sites include two conserved sequences, namely, the A-box and B-box (Figure S1), that are separated by seven base pairs with variable sequences. Residues in the HTH motif of Rob determine the shape and electrostatic interactions with the A-box sequence. Trp36 can make a van der Waals contact with Cyt7, whereas Arg40 can form a H bond with the $\mathrm{O}^{6}$ atom of Gua6. The Rob A-box sequence interactions compare well with data found for MarA in complex with its promoter. ${ }^{18}$

The second HTH motif in all members of the AraC/XylS family of transcriptional factors contains a cluster of highly conserved polar residues, which can bind within the B-box in cognate DNA promoters. ${ }^{18}$ Two conserved residues (Arg90 and Lys94) were found as ligands during the crystallographic study of the Rob-DNA complex. ${ }^{18}$ Despite the high homology between Rob and MarA, some differences were found in regard to Rob's contacts with the B-box. In the case of MarA, Arg96 located in helix $a \mathrm{~F}$ forms direct $\mathrm{H}$ bonds with two purines, Gua15 and Ade $7^{\prime}$ (numbered as in the micF structure). ${ }^{23}$

However, these two purines are not conserved in the binding sites for Rob, Mar, and Sox. The contacts between Mar and the B-box of mar DNA more likely include water-mediated $\mathrm{H}$ bonds. ${ }^{23}$ In the case of Rob Arg90, which is also situated within helix $a \mathrm{~F}$ and located in close proximity to micFDNA, binding with the DNA backbone is mediated via a $\mathrm{H}$ bond with the $5^{\prime}$-phosphate of Thy $14 .^{18}$

In this study, we have extended our analysis of the interaction of Rob protein with its micF promoter DNA by utilizing several purine nucleobase amino acids as analogues of a key Rob amino acid. The protein-DNA crystal structure suggests that residues Arg40 and Arg90 in adjacent HTH structures within Rob interact directly with the A-box and B-box of the micF promoter DNA, respectively. The relevant interactions are illustrated in Figure 1. By molecular modeling and the use of side-chain-altered analogues of arginine (norarginine and homoarginine, Figure 2), we determined that there can be some flexibility in the length or conformation of the side chain at this position. Accordingly, it seemed possible that the nucleobase amino acid that is structurally related to guanine (1) might well serve as a rigid isostere of Arg90 (Figure 2) and increase the affinity of Rob for its DNA promoter. We 
demonstrated that this replacement did enhance the mic $F$ Rob affinity, and that three nucleobase analogues of 1 (Figure 2, 2-4) had the expected effects on the protein-DNA affinity. By studying amino acid analogues that are predominantly capable of either base pairing or base stacking interactions, we found that these gave distinctly different results when introduced into position 40 or 90 . These observations supported the conclusion that different DNA sequences exhibited preferences for different types of protein interactions and demonstrated the ability of aromatic amino acids derived from nucleobases to utilize base stacking interactions to stabilize cognate protein-DNA interactions. Finally, by the use of assays that quantify the reported ability of Rob to induce resistance to macrolide antibiotics and heavy metal ions such as $\mathrm{Hg}^{2+}$, we demonstrated that the nucleobases in Rob that reinforce micFDNA binding using the same strategies as wild type resulted in enhanced antibiotic and heavy metal resistance, while those that increased binding by other molecular mechanisms did not enhance the resistance.

\section{MATERIALS AND METHODS}

\section{Synthesis of Amino Acids.}

The syntheses of amino acids not commercially available are discussed in the Supporting Information.

\section{Biochemical Experiments.}

Site-Directed Mutagenesis of the Rob Gene.-Rob gene mutagenesis corresponding to position Arg90 was done using a modified Quik-ChangeTN site-directed mutagenesis protocol. The pETRobwt plasmid, which has the wild-type rob gene, and the primers used were $5^{\prime}$-CTCTC-AACAG-ACATT-TACCC-TCGCA-TTCAAGAAG-CAGTTTG-3' for Rob90-Leu and 5'-CTCTCA-ACAGA-CATTT-ACCTA-GGCAT-TCAAGAAG-

CAGTTTG- ${ }^{\prime}$ for Rob proteins containing nucleobase amino acids. Primer oligonucleotide phosphorylation was carried out in a reaction mixture (20 $\mu \mathrm{L}$ total volume) that had 100 pmol of primer, $1 \mathrm{mM}$ ATP, $70 \mathrm{mM}$ Tris buffer (pH 7.6), $10 \mathrm{mM} \mathrm{MgCl}_{2}, 5 \mathrm{mM}$ DTT, and 1 unit of T4 polynucleotide kinase. These were incubated at $37^{\circ} \mathrm{C}$ for $1 \mathrm{~h}$ and then chilled on ice. Following the incubation, $40 \mu \mathrm{L}$ of deionized water, $240 \mu \mathrm{L}$ of $5 \mathrm{M} \mathrm{NH}_{4} \mathrm{OAc}$, and 750 $\mu \mathrm{L}$ of cold ethanol were added. The combined solution was mixed, incubated $\left(-20{ }^{\circ} \mathrm{C}\right.$ for 20 $\mathrm{min}$ ), and centrifuged (12 $000 \times g$ for $20 \mathrm{~min}$ ). The pellet was washed with $70 \%$ ethanol, airdried, and then dissolved in $50 \mu \mathrm{L}$ of RNase-free water.

The polymerase chain reaction (PCR) was carried out using $50 \mu \mathrm{L}$ (total volume) of $35 \mathrm{mM}$ Tris- $\mathrm{HCl}$ (pH 8.0) which contained $300 \mathrm{ng}$ of template, 14 pmol of primer, $10 \mathrm{nmol}$ of dNTPs, $12 \mathrm{mM}$ KOAc, $5 \mathrm{mM}$ DTT, 0.05\% Triton X-100, $0.05 \mathrm{mM}$ EDTA, $2.5 \mathrm{U}$ of Pfu polymerase, and $20 \mathrm{U}$ of Taq DNA ligase. The programming for the terminal cycler was as follows: pre-incubation at $95^{\circ} \mathrm{C}$ for $2 \mathrm{~min} ; 18$ cycles for $1 \mathrm{~min}$ at $95^{\circ} \mathrm{C}, 1 \mathrm{~min}$ at $45^{\circ} \mathrm{C}$, and $12 \mathrm{~min}$ at $65^{\circ} \mathrm{C}$; and then a final extension at $72{ }^{\circ} \mathrm{C}$ for $7 \mathrm{~min}$, after which the reaction mixture was allowed to cool to room temperature. Next, $1 \mu \mathrm{L}$ of restriction endonuclease DpnI was added, and the reaction mixture was incubated at $37{ }^{\circ} \mathrm{C}$ for $2 \mathrm{~h}$. The sample was then denatured at $95{ }^{\circ} \mathrm{C}$ for $1 \mathrm{~min}$, followed by two cycles at $95^{\circ} \mathrm{C}$ for $1 \mathrm{~min}, 50^{\circ} \mathrm{C}$ for 1

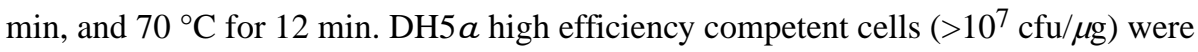


transformed using $5 \mu \mathrm{L}$ of the PCR product for each $50 \mu \mathrm{L}$ of cell suspension. The transformants were placed on the LB agar, prepared with $60 \mu \mathrm{g} / \mathrm{mL}$ kanamycin, and incubated at $37^{\circ} \mathrm{C}$ for $18-24 \mathrm{~h}$.

Preparation of Cells and Overexpression of Rob Proteins.-The individual wildtype and modified rob genes were introduced into plasmids and co-transformed with pTECHPly-OP in BL-21(DE-3) competent cells. Single colonies of these cells were cultured in a 2YT medium, which had been supplemented with $30 \mu \mathrm{g} / \mathrm{mL}$ chloramphenicol and 60 $\mu \mathrm{g} / \mathrm{mL}$ kanamycin; the isolated cells were maintained at $-80{ }^{\circ} \mathrm{C}(15 \%$ glycerol stocks $)$ until they were used. The initial growth of the cultures for in vivo expression employed $5 \mathrm{~mL}$ of the 2YT medium, which was supplemented with two antibiotics, until an $\mathrm{OD}_{600}$ value of $\sim 0.5$ was reached. Next, $3 \mathrm{~mL}$ aliquots of each culture were mixed with $3 \mathrm{~mL}$ of $30 \%$ glycerol. These aliquots were maintained at $-80{ }^{\circ} \mathrm{C}$ until further use in in vivo assays. Following the transfer of the samples into flasks with $30 \mathrm{~mL}$ of the $2 \mathrm{YT}$ medium supplemented with the two antibiotics, protein production was activated by the addition of IPTG to a $1 \mathrm{mM}$ concentration. At the same time, the amino acids to be incorporated into Rob were added to the culture containing the plasmid harboring the modified $r o b$ gene; the final amino acid concentration was $2-3 \mathrm{mM}$. Following incubation at $37{ }^{\circ} \mathrm{C}$ overnight, the cultures were centrifuged $\left(3500 \times g\right.$ at $4{ }^{\circ} \mathrm{C}$ for $\left.10 \mathrm{~min}\right)$. Cell pellets were resuspended in a lysis buffer consisting of $50 \mathrm{mM}$ Tris- $\mathrm{HCl}$ (pH 8.0) supplemented with $10 \mu \mathrm{g} / \mathrm{mL}$ lysozyme, and three freeze-thaw cycles were carried out. The samples from the last frozen step were centrifuged at $15000 \times g$ at $4{ }^{\circ} \mathrm{C}$ for $1 \mathrm{~h}$. Samples of the supernatants containing the culture lysates were transferred to fresh tubes and maintained on ice until they were used for protein purification.

Protein Purification.-For Rob protein purification, the culture lysates were diluted $\sim 3$ fold with $100 \mathrm{mM}$ Tris- $\mathrm{HCl}(\mathrm{pH}$ 8.3) and applied to a $100 \mu \mathrm{L}$ Strep-Tactin Sepharose column. Then, they were equilibrated and washed with $2 \mathrm{~mL}$ of the same buffer. The bound proteins were eluted with $0.5 \mathrm{~mL}$ of the same buffer, which was supplemented with $2.5 \mathrm{mM}$ desthiobiotin. Finally, the samples were concentrated and desalted using a $10 \mathrm{kDa}$ filtration device (Amicon Ultra, Millipore Corp). The samples were stored in $50 \mathrm{mM}$ Tris- $\mathrm{HCl}$ ( $\mathrm{pH}$ 7.4) that contained $30 \%$ glycerol. Samples were analyzed by $15 \%$ polyacrylamide-SDS gel electrophoresis following Coomassie R-250 staining (Figure S2). Defined amounts of a commercial sample of lysozyme were used for calibration to estimate the amount of protein in the individual Rob samples.

EMSA.-Electrophoretic mobility shift assays were carried out using micF and micFmutB promoter DNA sequences. $5^{\prime}{ }^{32} \mathrm{P}$-end-labeled DNA substrates were prepared by 32P-ATP labeling in $50 \mu \mathrm{L}$ reaction mixtures with $1 \mathrm{pmol}$ of oligonucleotides $5^{\prime}$ -

TGACAGCACTGAATGTCAAAG-3 ${ }^{\prime}$ and $5^{\prime}$-TGACAATACTGAATGTCAAAG- $3^{\prime}$ for the micF and micFmutB promoter DNAs, respectively, as well as 3.4 pmol of $5^{\prime}{ }^{\prime} \gamma_{-}{ }^{32} \mathrm{P}-\mathrm{ATP}$ (6000 Ci/mmol, $10 \mu \mathrm{Ci} / \mu \mathrm{L}$ ), $70 \mathrm{mM}$ Tris buffer (pH 7.6) containing $10 \mathrm{mM} \mathrm{MgCl}_{2}, 5 \mathrm{mM}$ DTT, and 1 unit of T4 PNK (Promega). Following incubation for $2 \mathrm{~h}$ at $37{ }^{\circ} \mathrm{C}$, the radiolabeled oligonucleotides were purified on MicroSpin G-25 columns (GE Healthcare) and mixed with 5 pmol of the corresponding complementary oligonucleotides. The reaction 
mixtures were incubated at $90{ }^{\circ} \mathrm{C}$ for $5 \mathrm{~min}$ and allowed to cool slowly to $37^{\circ} \mathrm{C}$ ( $\left.\sim 30 \mathrm{~min}\right)$. The final ${ }^{32} \mathrm{P}$-DNA substrates were diluted 2-fold using a $2 \times$ DNA binding buffer $(40 \mathrm{mM}$ Tris (pH 8.0), $100 \mathrm{mM} \mathrm{NaCl}$, and $10 \%$ glycerol). The final concentration of the ${ }^{32} \mathrm{P}$-labeled DNA substrates was $6 \mathrm{nM}$. For EMSA, Rob samples were first diluted using a DNA binding buffer to a concentration of $500 \mathrm{nM}$. Next, four successive 2 -fold dilutions were then carried out. Then, $3 \mu \mathrm{L}$ of each dilution was mixed with $3 \mu \mathrm{L}$ of the ${ }^{32} \mathrm{P}$-labeled DNA substrate, and the reaction mixtures were incubated for $15 \mathrm{~min}$ at ambient temperature. Next, $3 \mu \mathrm{L}$ of the native electrophoresis loading buffer $(0.05 \%$ xylene cyanol FF and $0.05 \%$ bromphenol blue in 50\% glycerol) was added to each sample. The samples were then loaded on $10 \%$ native polyacryalamide gels, and electrophoresis was run for $1.5 \mathrm{~h}$ at $80 \mathrm{~V}$. The amount of bound and free DNA was analyzed using a phosphorimager. The $\mathrm{BC}_{50}$ value was determined on the basis of an Excel program using the initial linear part of the curve to represent the percent of bound DNA relative to total DNA in samples vs the concentration of protein in the samples.

Antibiotic Sensitivity Assay.-Cultures of BL-21(DE-3)-Pyl with different amounts of plasmids, pET28b (negative control), pETRobwt (positive control), and pETRob90 were prepared as described above after a cotransformation of the BL-21(DE-3) strain. Before each assay, fresh cultures were prepared by adding $\sim 10 \mu \mathrm{L}$ aliquots of the glycerol stocks to $3 \mathrm{~mL}$ of an LB medium ( $\mathrm{pH}$ 6.9) supplemented with kanamycin $(60 \mu \mathrm{g} / \mathrm{mL})$ and chloramphenicol ( $30 \mu \mathrm{g} / \mathrm{mL}$ ). The cultures were incubated for about $3-4 \mathrm{~h}$ at $37{ }^{\circ} \mathrm{C}$ until the $\mathrm{OD}_{600}$ value was about 0.5 . For the assays, the cultures were diluted to an $\mathrm{OD}_{600}$ value of 0.01 for the $\mathrm{pET} 28 \mathrm{~b}$ and pETRobwt cultures using an LB medium ( $\mathrm{pH} 8.8$ ), and to an $\mathrm{OD}_{600}$ value of 0.3 for the pETRob40 cultures. The LB medium was also supplemented with kanamycin $(60 \mu \mathrm{g} / \mathrm{mL})$, chloramphenicol (30 $\mu \mathrm{g} / \mathrm{mL})$, and IPTG (1 mM). For the assays of Rob samples with different amino acids in position 90, the corresponding amino acids were added to the medium to a final concentration of $2 \mathrm{mM}$ prior to each assay. Then, 96-well plates containing the antibiotics roxithromycin and clarithromycin at $50-3.12 \mu \mathrm{g} / \mathrm{mL}$ dilutions were prepared in an LB medium with chloramphenicol, kanamycin, and IPTG. Each dilution of the macrolides was mixed with an assay solution of BL-21(DE-3)-Pyl cultures and incubated overnight at $37^{\circ} \mathrm{C}$. For each culture, the $\mathrm{OD}_{600}$ values were measured and the $\mathrm{IC}_{50}$ values were calculated. In the case of the ampicillin sensitivity study, an LB medium of $\mathrm{pH} 6.9$ was used for the assay, and all the cultures were tested at multiple concentrations of the antibiotic dilutions between 0.2 and $25 \mu \mathrm{g} / \mathrm{mL}$.

Assay for Resistance to $\mathbf{H g}^{2+}$._Assay cultures were prepared as described above using an LB medium ( $\mathrm{pH}$ 8.0) supplemented with kanamycin, chloramphenicol, and IPTG. Six dilutions of $\mathrm{HgCl}_{2}(100-3.12 \mu \mathrm{g} / \mathrm{mL})$ were prepared using the same medium in 96-well plates. Tested samples of the BL-21(DE-3)-Pyl cultures were mixed with each dilution of $\mathrm{HgCl}_{2}$; the final concentrations of $\mathrm{HgCl}_{2}$ in the assay were $50-1.56 \mu \mathrm{g} / \mathrm{mL}$. The final 96well plates were incubated overnight at $37^{\circ} \mathrm{C}$. For each culture, the $\mathrm{OD}_{600}$ values were measured and the $\mathrm{IC}_{50}$ values were calculated.

\section{RESULTS AND DISCUSSION}

Figure 1 is an analysis of the structural elements in the Rob protein and its micFDNA promoter that have been identified by $\mathrm{X}$-ray crystallographic analysis as important to the 
binding of these two species. These include the following two arginine residues, each within a separate helix-turn-helix motif, which have been shown by X-ray crystallography to associate with different elements in the micF promoter DNA ${ }^{18}$ (Figure S1): Arg40, in which the side chain is not fully extended (5.94 $\AA$ between $\mathrm{C}^{a}$ of $\mathrm{Arg}$ and the side chain $\mathrm{NH}_{2}$ group that coordinates $\mathrm{O}^{6}$ of Gua-6), and $\mathrm{Arg} 90$, which is slightly more fully extended and makes contact with the phosphate ester oxygen adjacent to Thy14 (6.09 ^ between $\mathrm{C}^{a}$ of Arg and the side chain $\mathrm{NH}_{2}$ group). We initially introduced norarginine and homoarginine into position 90 and found that the binding of these modified Rob proteins to micFDNA was essentially unaltered, with values of $63 \pm 11 \mathrm{nM}$ for Rob-wt, and $56 \pm 16$ and $47 \pm 8 \mathrm{nM}$ for Rob analogues containing norarginine and homoarginine, respectively (Table 1 and Figure 3). This suggested that small changes in the positions of key functional amino acids might be tolerated functionally, perhaps by adjustments in the side chain conformation. Accordingly, specific (nucleobase) amino acids (Figure 2) were incorporated singly into both of these Rob positions to determine whether the molecular behaviors suggested by the crystal structure could also be used to enhance the implied interactions selectively by the use of such conformationally constrained nucleobase amino acids.

As shown in Table 1, the introduction of guanine nucleobase amino acid 1 at position 90 in lieu of arginine produced a protein-DNA interaction at least as strong as that induced by wild-type Rob ( $\mathrm{BC}_{50} 39 \pm 2$ vs $63 \pm 11 \mathrm{nM}$ ), which is consistent with the possibility of having the exocyclic $\mathrm{NH}_{2}$ group of 1 interact directly with the phosphate oxygen to the $5^{\prime}$ side of Thy 14 (Figure 1, lower panel). ${ }^{18}$ The atoms in arginine and the guanine nucleobase amino acid 1, which are colored in red in Figure 2, highlight this possibility. Modified Rob proteins containing nucleobases 2 and 3 at position 90, which are capable of the same interaction, also exhibited strong micFDNA binding (Table 1 and Figure 4). Thus, Rob90-2 exhibited a $\mathrm{BC}_{50}$ value of $38 \pm 5 \mathrm{nM}$, while that for Rob90-3 was $41 \pm 4 \mathrm{nM}$. In comparison, the binding of Rob90-4 to micFDNA was weaker (BC $5080 \pm 10 \mathrm{nM}$ ), presumably reflecting the effects of the absence of an exocyclic 2- $\mathrm{NH}_{2}$ group (Table 1). The obvious effect of the presence or absence of the 2- $\mathrm{NH}_{2}$ group in 1-4 in modified Rob proteins on the interaction with micFDNA strongly supports the thesis that compounds 1,2 , and 3 likely behave as conformationally constrained arginine analogues.

The preceding data support the interpretation that the side chains of $\operatorname{Arg} 90$ and its close structural congeners, such as norarginine and homoarginine, have a range of lengths appropriate for supporting the Rob interaction with the Thy $145^{\prime}$-phosphate oxygen atom via $\mathrm{H}$ bonding (Figure 1, bottom panel), and verify that conformational constraints, such as those imposed by the bicyclic ring structures in nucleobase amino acids $1-3$, can produce enhanced DNA substrate binding. Perhaps as importantly, the data obtained for the Rob proteins containing norarginine and homoarginine help to define the range of differences in the distances for individual amino acids that can be accommodated in the Rob-micFDNA complexes by adjustments of the side chain conformations. This may ultimately prove to be exceptionally helpful in the design of new nucleobase analogues as the constituents of proteins.

It is interesting to note that the preferred interactions between two arginine residues ( $\operatorname{Arg} 40$ and Arg90) and micFDNA, both of which involve residues that are part of helix-turn-helix 
motifs, involve different types of DNA binding partners, namely, the $\mathrm{O}^{6}$ functionality of nucleotide Gua6 (for Arg40) and a phosphodiester O adjacent to Thy 14 (for Arg90). This was true even though the distances between the $\mathrm{C}^{a}$ atom and the coordinating side chain $\mathrm{NH}_{2}$ group were quite similar for each (5.94 and 6.09 $\AA$ for Arg40 and Arg90, respectively) and the replacement of Arg90 with Arg analogues that had shorter and longer side chains (norArg and homoArg, respectively) did not seem to alter the nature of DNA binding (Table 1). We showed previously ${ }^{24}$ that a cytidine nucleobase amino acid placed at Rob position 40 enhanced binding to Gua6, putatively by forming a Watson-Crick-like $\mathrm{H}$ bond with Gua6. It is possible that the introduction of adenine amino acid 5 into Rob position 90 permits a Watson-Crick-like interaction $\left(\mathrm{BC}_{50} 56 \pm 12 \mathrm{nM}\right)$ with Thy 14 (Table 1).

Another approach to understanding the nature of the molecular interaction of $\operatorname{Arg} 90$ with the B-box of micFDNA involved the alteration of the DNA itself. As shown in Figure 5, Cyt17 was altered to a deoxyguanosine ( $m i c F m u t B$ ), affording a DNA strand locally very rich in purine nucleotides. While not known to be involved in the Rob-micFDNA interaction, as shown in Figure 5 and Table 2, this alteration of the DNA structure caused a modest decrease in the affinity of wild-type Rob for its DNA target ( $63 \mathrm{nM} \mathrm{BC}_{50}$ for micFDNA vs $83 \mathrm{nM} \mathrm{BC}_{50}$ for micFmutB DNA). This limited change was entirely consistent with the earlier finding ${ }^{24,25}$ that structural alterations of A-box nucleotides had a much greater effect on Rob affinity for the DNA promoter than changes in the B-box nucleotides. A more interesting finding involved the modified Rob containing nucleobase 1 at position 90 in lieu of arginine (Rob90-1). As shown in Figure 5 and Table 2, the replacement of Arg90 by nucleobase amino acid 1 enhanced the interaction with micFDNA $\left(\mathrm{BC}_{50} 39 \pm 2 \mathrm{nM}\right.$ for Rob90-1 vs $63 \pm 11 \mathrm{nM}$ for Rob-wt) but greatly lowered Rob affinity for micFmutB DNA $\left(\mathrm{BC}_{50} 220 \pm 20 \mathrm{nM}\right.$ for Rob90-1 vs $83 \pm 3 \mathrm{nM}$ for Robwt). Significantly, when Arg90 was replaced with naphthylalanine, giving Rob90-Naph, the affinities for micF and micFmutB DNAs both increased significantly and to about the same extent $\left(\mathrm{BC}_{50} 34 \pm 6 \mathrm{nM}\right.$ for micF vs $45 \pm 4 \mathrm{nM}$ for micFmutB). These findings strongly support the hypothesis that guanine nucleobase amino acid 1 can substitute for arginine in position 90 , actually increasing the binding to micFDNA; this was also suggested by the data in Figure 4. However, the data also suggest that Rob containing naphthylalanine may be capable of binding to the DNA by an alternative mechanism, whereas Rob90-1, which was designed to be more rigid in proximity to position 90 than Rob-wt, cannot easily accommodate binding to more purinerich micFmutB while simultaneously maintaining the contact it employs in binding to the Bbox of Rob-wt.

The preceding data involving Rob90 substituted with naphthylalanine suggest strongly that Rob containing this amino acid can bind to DNA by a different mechanism than Rob containing 1. While we noted the possibility of weak base stacking in an earlier publication dealing with position 40 of the Rob protein, ${ }^{24}$ the affinities measured in this study were significantly greater and suggested the need for a systematic comparison. Accordingly, we prepared several modified Rob proteins substituted at either position 40 or position 90 with the same amino acids. This included amino acids 1 and 5 (Figure S3) as well as naphthylalanine and phenylalanine at position 90 (Figure S4), the latter of which had previously been introduced into position $40 .^{24} \mathrm{~A}$ summary of the $\mathrm{BC}_{50}$ values calculated from the EMSA assays is shown in Table 3. As shown, all substitutions with the same amino 
acids gave stronger affinities at position 90 than at position 40 in spite of the reported ${ }^{25}$ lesser importance of the B-box interaction with Rob. The lower value for amino acid 1 at position 90 was no surprise, given its resemblance to arginine (vide supra) and greater conformational rigidity than the canonical amino acid Arg. The results obtained for Rob905 and Rob90-Phe as well as Rob90-Naph are consistent with a binding mechanism involving the base stacking of these Rob proteins to the (purine-rich) B-box of the micFDNA.

However, it should be noted that the molecular basis of the observed binding of Rob90-5 to micFDNA may also reflect the Watson-Crick-like binding of 5 to Thy14 (vide supra). The loss of affinity of Rob90-1 when the DNA promoter was made more purine-rich on the target strand $(\mathrm{micF} \rightarrow$ micFmutB) also supports the interpretation that the binding mechanism was impacted by the change in the DNA target structure.

In a recent publication, ${ }^{24}$ we demonstrated that the introduction of nucleobase amino acids capable of DNA-target $\mathrm{H}$ bonding into Rob position 40 enhanced the affinity of this protein for micFDNA, while those lacking such $\mathrm{H}$ bonding properties exhibited a decreased DNA affinity. Furthermore, the modified Rob proteins displaying enhanced affinity also exhibited a greater resistance to the macrolide antibiotics roxithromycin and clarithromycin than that of wild-type Rob. Increased antibiotic resistance to certain antibiotics is a known phenotype of altered Rob expression, apparently mediated at the level of expression of the export protein OmpF. ${ }^{4-9}$ Accordingly, it seemed of interest to determine the effects of the alteration of Rob position 90 on antibiotic resistance.

As shown in Figure 6, the overexpression of Rob90-1, Rob90-2, and Rob90-3 in E. coli increased the bacterial resistance to roxithromycin 2- to 3-fold as compared with that of wild-type Rob, while the overexpression of Rob90-4 in E. coli resulted in a resistance to roxithromycin approximately as great as that of wild-type Rob. In comparison, Rob90-Naph, which bound to micF promoter DNA roughly twice as strongly as Rob-wt and at least as strongly as Rob90-1 (Table 2), induced not dramatically more roxithromycin resistance than that of wild-type Rob and only about one-half that of Rob90-1.

In addition to its phenotypic effect on antibiotic resistance, the overexpression of Rob has also been shown to confer a diminished sensitivity to certain heavy metals. ${ }^{26}$ To test the phenotypic effects of the modified Rob proteins further, we established an assay in which $\mathrm{HgCl}_{2}$ inhibited the growth of $E$. coli and became more tolerant to this salt when plasmidborne Rob-wt was overexpressed (Figure S5). This assay was then used to test the ability of several modified Rob proteins to affect the sensitivity of E. coli to $\mathrm{Hg}^{2+}$ (Figure 7). As shown in Figure 7, the $\mathrm{IC}_{50}$ value of $\mathrm{Hg}^{2+}$ in E. coli expressing Rob90-1 was 2-3-fold greater than that of Rob-wt ( $21 \pm 2 \mathrm{vs} 7.6 \pm 3 \mu \mathrm{g} / \mathrm{mL}$, respectively). The overexpression of Rob 90-2 also resulted in an increase in E. coli tolerance to $\mathrm{Hg}^{2+}$, but Rob90-3, Rob90-4, and Rob90-5 produced about as much tolerance to $\mathrm{Hg}^{2+}$ as Rob-wt $(10.7 \pm 1.5,8.8 \pm 2.5$, and $8.1 \pm 1 \mu \mathrm{g} / \mathrm{mL}$, respectively). For two of them, Rob 90-4 and Rob 90-5, this was consistent with their similar affinities for the micF promoter DNA (Table 1). Notably, Rob90-Naph had greater effect on $\mathrm{Hg}^{2+}$ tolerance than that of overexpressed wild-type Rob, and the other modified proteins tested were not significantly greater than that of the wild type. 
There are two important conclusions from the preceding experiments. The first is that Rob proteins containing nucleobase amino acids can exhibit enhanced binding to their DNA promoter relative to that of the wild type, and that this binding can produce phenotypic responses in vivo greater than that accessible by the use of the native system. The second is that the use of nucleobase amino acids as mimics of natural amino acids can be a promising molecular strategy for studying DNA binding in native systems. While nucleobase amino acids permit the use of non-natural interactions to enhance protein-DNA binding, including one which seems to involve a stacking mechanism, the present altered mechanism has not been found to induce significant enhancements in the phenotypic responses mediated by the native system. It seems likely that the phenotypic response relies both on Rob-DNA affinity and also on the specific mode of the molecular interactions between the protein and its DNA target. Finally, there is also an important implication of these studies. While the present work is focused on mimicking and enhancing the properties of canonical amino acids with nucleobase amino acids that have predictable $\mathrm{H}$ bonding properties, it seems logical to anticipate that the enhanced protein-DNA binding with nucleobase amino acids could enable altered sites of DNA binding by stabilizing interactions not normally accessible to proteins composed entirely of canonical amino acids. While these studies were not designed to provide insight into the way in which Rob chooses its preferred binding site on the DNA, once the preferred mode of binding is known this does potentially suggest strategies for altering the affinity and selectivity of binding.

An additional feature of these studies that is worth noting is that, while the introduction of nucleobase amino acids in a fashion envisioned to produce stabilizing interactions that are associated with increases in the binding affinity are supported by statistical analysis, the increases are not large. This may be intrinsic to dynamic systems that support modified functions analogous to the wild type, although further study is required to provide further insight and systems that employ simpler responses may be required for this purpose.

Electrophoretic gel shift assays using modified DNA substrates were performed with both Rob and MarA to study the importance of the promoter B-box for protein-DNA interactions (Figure S1). ${ }^{18}$ Two conserved thymidines, Thy $4^{\prime}$ and Thy 5' (complementary to Ade18 and Ade19 on the sense strand), were shown to contribute, albeit modestly, to the sequencespecific interaction of MarA with both micF and mar promoter DNAs through van der Waals contacts with the $\mathrm{C}^{5}$ methyl groups. This was established through the replacement of the thymidine residues with uridine and (5-propynyl)-uridine. ${ }^{18}$ However, no analogous change was observed for the interaction of Rob with modified micF promoter DNAs. In an earlier study, single-base mutational analysis of positions 6-9 (A-box) of the micF promoter DNA led to 7- to 100-fold decreases in binding affinity by wild-type Rob, but single base mutational changes at promoter DNA positions 15 or 16 (immediately adjacent to the Bbox) resulted in only $\sim 3$-fold diminution of Rob binding. ${ }^{25}$ These findings led to the logical conclusion that the Rob-micF promoter DNA interaction depended more importantly on Rob interactions with the A-box of micFDNA rather than the B-box.

The observations noted above are not inconsistent with these previous reports, ${ }^{18,25}$ which were based on rather limited examples of protein binding to structurally altered DNA promoters. The only DNA structural change in the present report is outlined in Figure 5 and 
Table 2. A single base change (Cyt17 to Gua17) of the promoter sense strand in the B-box along with a change of the complementary nucleotide at position $6^{\prime}$ of the antisense strand had only a minimal effect on the Rob-micFDNA affinity $\left(\mathrm{BC}_{50}\right.$ values of $63 \mathrm{vs} 83 \mathrm{nM}$, respectively, Table 2). In a recent report from our laboratory, it was also shown that altering nucleotides 6 and 7 of the micF promoter DNA from GC to AT (A-box) resulted in a loss of Rob affinity from 63 to $2500 \mathrm{nM}{ }^{24}$ Thus, these experiments also suggest that the A-box protein-DNA interactions may be more important than those involving the B-box.

However, these more recent studies were intended to explore the effects of changing single amino acids in Rob (arginine residues 40 or 90) to nucleobase amino acids. ${ }^{24}$ The introduction of $\mathrm{H}$ bonding nucleobase amino acid mimics for the canonical arginine residues at either position afforded examples leading to an enhanced Rob-micFDNA affinity with the concomitant enhancement of phenotypic changes such as antibiotic resistance. However, while little if any base stacking effects were noted for the nucleobase amino acids introduced into the A-box at Rob position $40,{ }^{24}$ the effects of the species capable of base stacking were clearly more pronounced at position 90 of Rob, which interacts with the B-box of the micF DNA (Table 3); some of these produced fairly substantial changes in the Rob-micFDNA affinity. Thus far, none of these enhanced affinities resulting from the changes in Rob 90 seem to have led to the enhanced properties of Rob in conferring a resistance to antibiotics or $\mathrm{Hg}^{2+}$.

\section{Supplementary Material}

Refer to Web version on PubMed Central for supplementary material.

\section{ACKNOWLEDGMENTS}

We thank Prof. Dieter Söll for plasmid pTECH-Pyl-OP.

Funding

This study was supported by Research Grant GM12367 from the National Institute of General Medical Sciences, NIH.

\section{ABBREVIATIONS}

wt

no wild type

no Rob protein sequence in the vector

\section{REFERENCES}

(1). Delihas N, and Forst S (2001) MicF: an antisense RNA gene involved in response of Escherichia coli to global stress factors. J. Mol. Biol 313, 1-12. [PubMed: 11601842]

(2). Andersen J, Delihas N, Ikenaka K, Green PJ, Pines O, Ilercil O, and Inouye M (1987) The isolation and characterization of RNA coded by the micF gene in Escherichia coli. Nucleic Acids Res. 15, 2089-2101. [PubMed: 2436145]

(3). Vogel J, and Papenfort K (2006) Small non-coding RNAs and the bacterial outer membrane. Curr. Opin. Microbiol 9, 605-611. [PubMed: 17055775] 
(4). Pratt LA, Hsing W, Gibson KE, and Silhavy TJ (1996) From acids to osmZ: multiple factors influence synthesis on the $\mathrm{OmpF}$ and $\mathrm{OmpC}$ porins in Escherichia coli. Mol. Microbiol 20, $911-$ 917. [PubMed: 8809744]

(5). Nikaido H (1992) Porins and specific channel of bacterial outer membranes. Mol. Microbiol 6, 435-442. [PubMed: 1373213]

(6). Masi M, and Pages JM (2013) Structural, function and regulation of outer membrane proteins involved in drug transport in Enterobactericeae: the OmpF/C-TolC cases. Open Microbiol. J 7, 22-33. [PubMed: 23569467]

(7). Nikaido H (1994) Prevention of drug access to bacterial targets: permeability barrier and active efflux. Science 264, 382-388. [PubMed: 8153625]

(8). Miller PF, and Sulavik MC (1996) Overlaps and parallels in regulation of intrinsic multipleantibiotic resistance in Escherichia coli. Mol. Microbiol 21, 441-448. [PubMed: 8866468]

(9). Andersen F, Forst SA, Zhao K, Inouye M, and Delihas N (1989) The function of micFRNA: micF RNA is a major factor in the thermal regulation of OmpF protein in Escherichia coli. J. Biol. Chem 264, 17961-17970. [PubMed: 2478539]

(10). Gallegos MT, Schleif R, Bairoch A, Hofmann K, and Ramos JL (1997) AraC/XylS family of transcriptional regulators. Microbiol. Mol. Biol 61, 393-410.

(11). Chubiz LM, and Rao CV (2011) Role of the mar-sox-rob regulon in regulating outer membrane porin expression. J. Bacteriol 193, 2252-2260. [PubMed: 21398557]

(12). Jair KW, Yu X, Skarstad K, Thöny B, Fujita TB, Ishihama A, and Wolf RE Jr. (1996) Transcriptional activation of promoters of the superoxide and multiple antibiotic resistance regulons by Rob, a binding protein of the Escherichia coli origin of chromosomal replication. J. Bacteriol 178, 2507-2513. [PubMed: 8626315]

(13). Martin R, and Rosner JL (2002) Genomics of the marA/soxS/rob regulon in Escherichia coli: identification of directly activated promotors by application of molecular genetics and informatics in microarray data. Mol. Microbiol 44, 1611-1624. [PubMed: 12067348]

(14). Taliaferro LP, Keen EF III, Sanchez-Alberola N, and Wolf R Jr. (2012) Transcription activation by Escherichia coli Rob at class II promoters: protein-protein interactions between Rob's Nterminal domain and $\sigma^{70}$ subunit of RNA polymerase. J. Mol. Biol 419, 139-157. [PubMed: 22465792]

(15). Bennik MH, Pomposiello PJ, Thorne DF, and Demple B (2000) Defining a rob regulon in Escherichia coli by using transposon mutagenesis. J. Bacteriol 182, 3794-3801. [PubMed: 10850996]

(16). Oh JT, Cajal Y, Skowronska EM, Belkin S, Chen J, Van Dyk TK, Sasser M, and Jain MK (2000) Cationic peptide antimicrobials induce selective transcription of micF and osm Y in Escherichia coli. Biochim. Biophys. Acta, Biomembr 1463, 43-54.

(17). McMurry LM, and Levy SB (2010) Evidence that regulatory protein MarA of Escherichia coli represses rob by steric hindrance. J. Bacteriol 192, 3977-3982. [PubMed: 20453091]

(18). Kwon H, Bennik MHJ, Demple B, and Ellenberger T (2000) Crystal structure of the Escherichia coli Rob transcriptional factors in complex with DNA. Nat. Struct. Biol 7, 424-430. [PubMed: 10802742]

(19). Rhee S, Martin RG, Rosner JL, and Davies DR (1998) A novel DNA binding motif in MarA: the first structure for an AraC family transcriptional activator. Proc. Natl. Acad. Sci. U. S. A 95, 10413-10418. [PubMed: 9724717]

(20). Griffith KL, Fitzpatrick MM, Keen EF III, and Wolf RE Jr. (2009) Two functions of the Cterminal domain of Escherichia coli Rob: mediating "sequestration-dispersal" as a novel off-on switch for regulating Rob's activity as a transcription activator and preventing degradation of Rob by Lon protease. J. Mol. Biol 388, 415-430. [PubMed: 19289129]

(21). Griffith KL, and Wolf RE Jr. (2001) Systemic mutagenesis of DNA binding sites for SoxS in Escherichia coli zwf and fpr promoters: identifying nucleotides required for DNA binding and transcriptional activation. Mol. Microbiol 40, 1141-1154. [PubMed: 11401718]

(22). Dangi B, Pelupessey P, Martin RG, Rosner JL, Louis JM, and Gronenborn AM (2001) Structure and dynamics of MarADNA complexes: an NMR investigation. J. Mol. Biol 314, 113-127. [PubMed: 11724537] 
(23). Martin RG, Gillette WK, Rhee S, and Rosner JL (1999) Structural requirements for marbox function in transcriptional activation of mar/sox/rob regulon promoters in Escherichia coli: Sequence, orientation and spatial relationship to the core promoter. Mol. Microbiol 34, 431-441. [PubMed: 10564485]

(24). Zhang C, Chen S, Bai X, Dedkova LM, and Hecht SM (2020) Alteration of transcriptional regulator Rob in vivo: enhancement of promoter DNA binding and antibiotic resistance in the presence of nucleobase amino acids. Biochemistry 59, 1217-1220. [PubMed: 32157864]

(25). Li Z, and Demple B (1996) Sequence specificity for DNA binding by Escherichia coli SoxS and Rob proteins. Mol. Microbiol 20, 937-945. [PubMed: 8809747]

(26). Nakajima H, Kobayashi K, Kobayashi M, Asako H, and Aono R (1995) Overexpression of the robA gene increases organic solvent tolerance and multiple antibiotic and heavy metal ion resistance in Escherichia coli. Appl. Environ. Microbiol 61, 2302-2307. [PubMed: 7793951] 

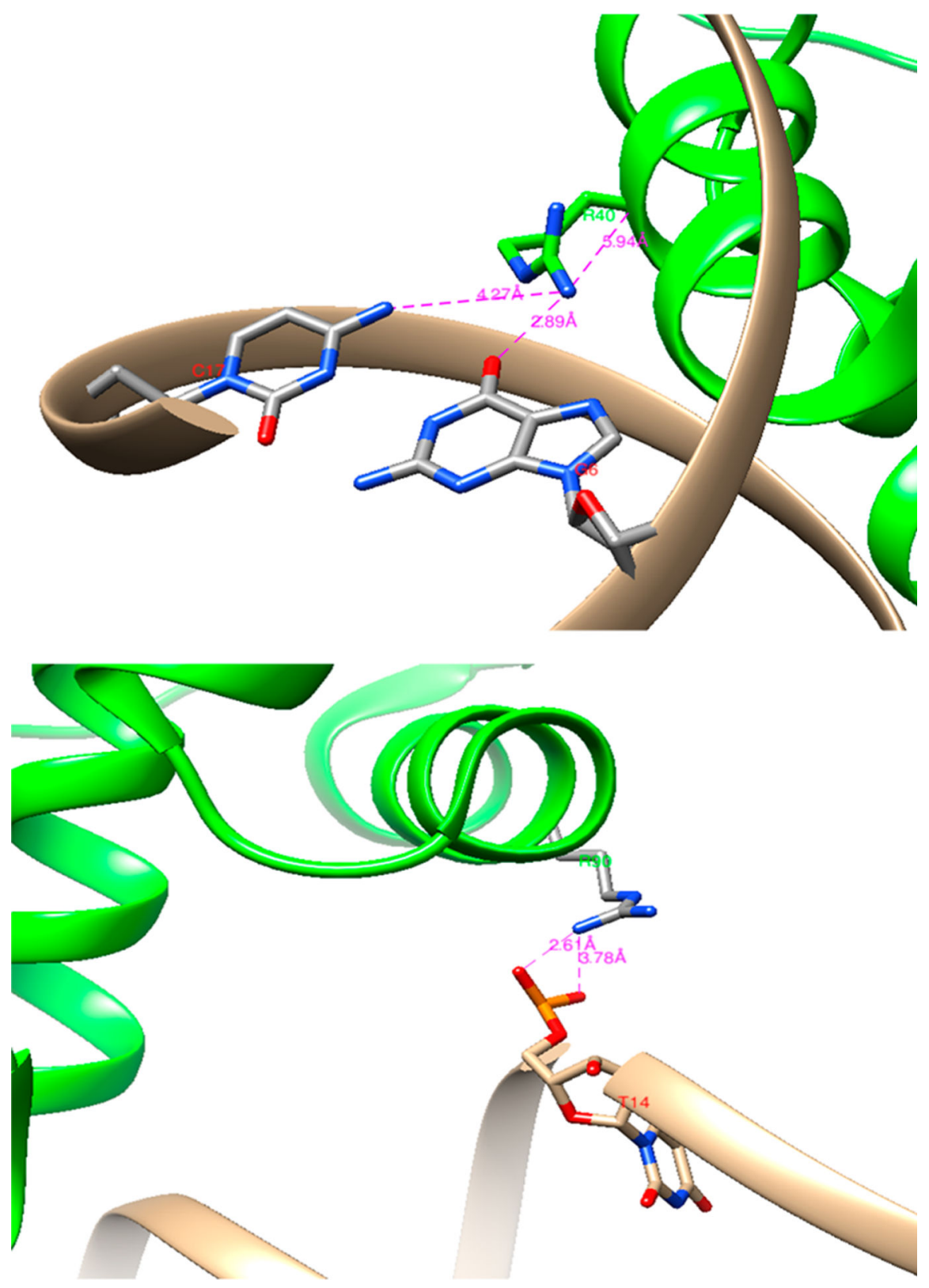

Figure 1.

Partial structures of the Rob protein-micF promoter DNA structure, ${ }^{18}$ illustrating the $\mathrm{H}$ bonding interactions between the $\mathrm{Arg} 40$ of Rob and the $\mathrm{O}^{6}$ of Gua6 in the micFDNA A-box (upper panel) and between the Arg90 of Rob and a phosphate oxygen anion at the $5^{\prime}$-end of Thy14 in the micF promoter DNA B-box (lower panel). 
<smiles>Nc1nc2c(ncn2CC(N)C(=O)O)c(=O)[nH]1</smiles><smiles>Nc1nc2c(ncn2CC(N)C(=O)O)c(=S)[nH]1</smiles><smiles>Nc1ncc2ncn(CC(N)C(=O)O)c2n1</smiles><smiles>NC(Cn1cnc2c(=O)[nH]cnc21)C(=O)O</smiles><smiles>Nc1ncnc2c1ncn2CC(N)C(=O)O</smiles><smiles>CC(C)CC(N)C(=O)O</smiles>

leucine<smiles>NC(Cc1ccccc1)C(=O)O</smiles>

phenylalanine<smiles>NC(Cc1ccc2ccccc2c1)C(=O)O</smiles>

naphthylalanine<smiles>C#CCCCNC(=N)NC(N)CCCNC(=N)N</smiles><smiles>N=C(N)NCCC(N)C(=O)O</smiles>

norarginine<smiles>N=C(N)NCCC[C@H](N)C(=O)O</smiles>

homoarginine

Figure 2.

Structures of the nucleobase and other $a$-amino acids used for the preparation of modified Rob proteins. 

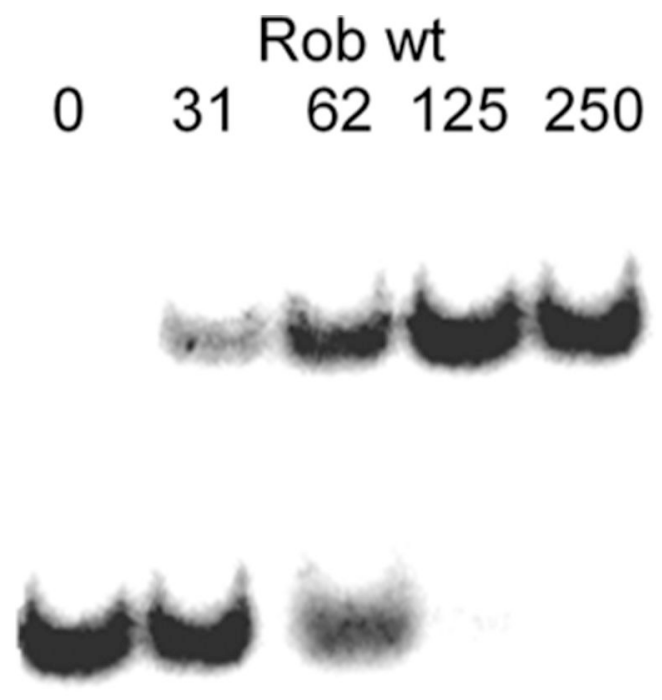

\section{Rob90-norArg Rob90-homoArg $\begin{array}{llllllllll}0 & 31 & 62 & 125 & 250 & 0 & 31 & 62 & 125 & 250 \\ \mathrm{nM}\end{array}$}
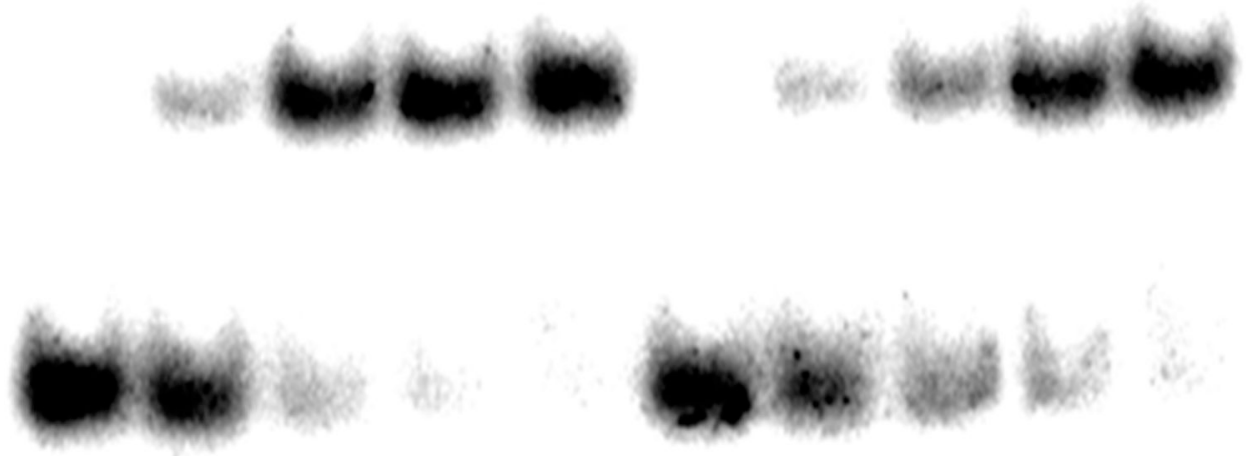

Figure 3.

EMSA of Rob90wt, Rob90-norarginine, and Rob90-homoarginine, which illustrates the similar affinities of all three for the micF promoter DNA. 


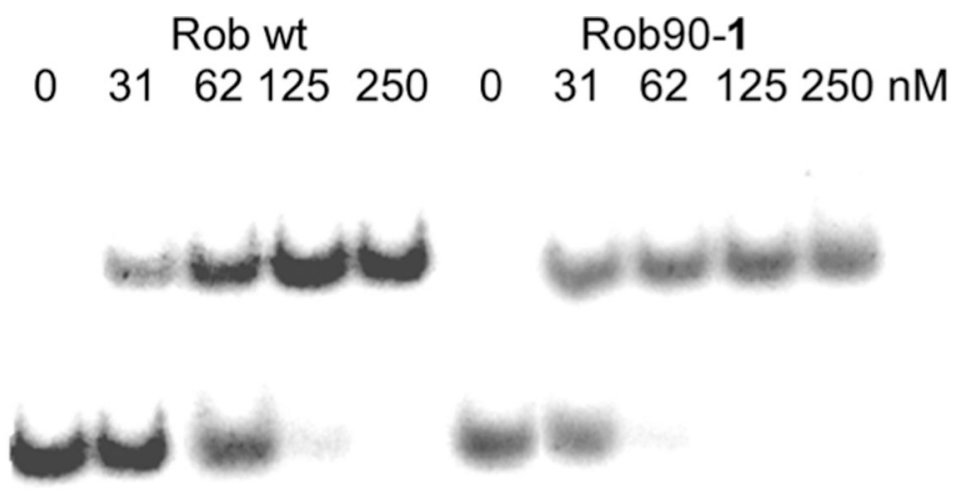

Rob90-2

$\begin{array}{lllllllllll}0 & 31 & 62 & 125 & 250 & 0 & 31 & 62 & 125 & 250 & \mathrm{nM}\end{array}$
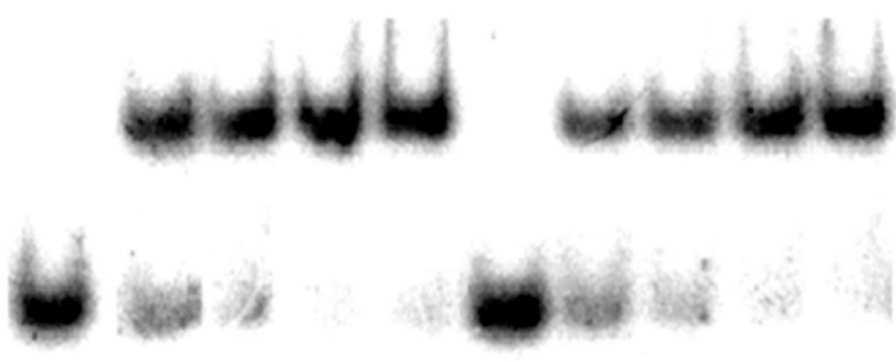

Rob90-4

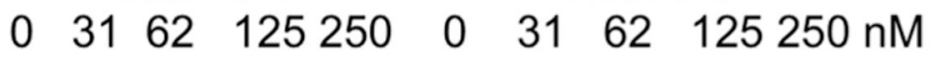
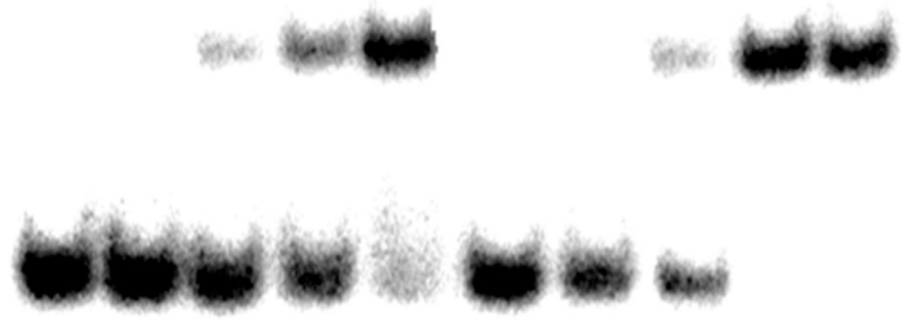

Figure 4.

The EMSA of Rob90-1, Rob90-2, and Rob90-3 that illustrate the enhanced binding of these proteins to micFDNA relative to wild type Rob, while Rob90-4 and Rob90-5 exhibit diminished binding. 


\title{
$\operatorname{mic} F$ \\ TGACAGCACTGAATGTCAAAG \\ micFmutB \\ TGACAGCACTGAATGTGAAAG
}

Rob-DNA complex

\author{
Robwt + micF $\quad$ Robwt + micFmutB \\ $\begin{array}{llllllll}0 & 62125250500 & 0 & 62 & 125 & 250 & 500 & \mathrm{nM}\end{array}$
}

DNA alone

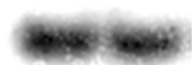

Rob90-1 + micFmutB Rob90-Naph + micFmutB

$\begin{array}{lllllllllll}0 & 31 & 62 & 125 & 250 & 0 & 31 & 62 & 125 & 250 & \mathrm{nM}\end{array}$

Rob-DNA complex

DNA alone

Figure 5.

Electrophoretic mobility shift assay (EMSA) analysis of the binding of wild-type Rob to micFDNA and micF-mutB DNA compared to the binding of modified Rob90-1 and Rob90Naph proteins to micF-mutB DNA. 


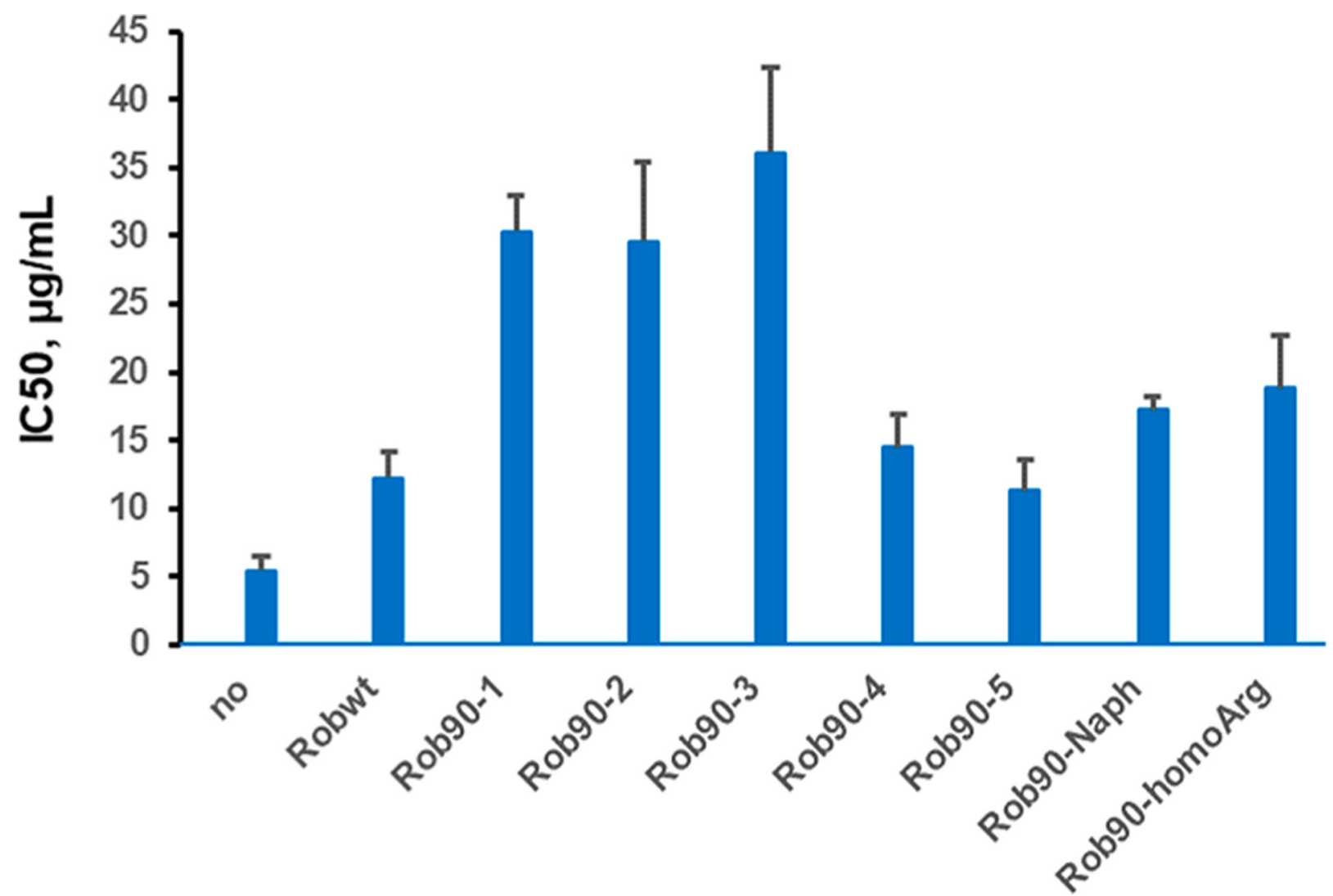

Figure 6.

Resistance of E. coli cultures overexpressing Rob-wt, Rob analogues containing nucleobase (1-5) amino acids, or naphthylalanine and homoarginine at position 90 to inhibition by the macrolide antibiotic roxithromycin ( $\mathrm{pH} 8.9)$. For Rob90-1 vs Rob-wt, $p<0.05$. 


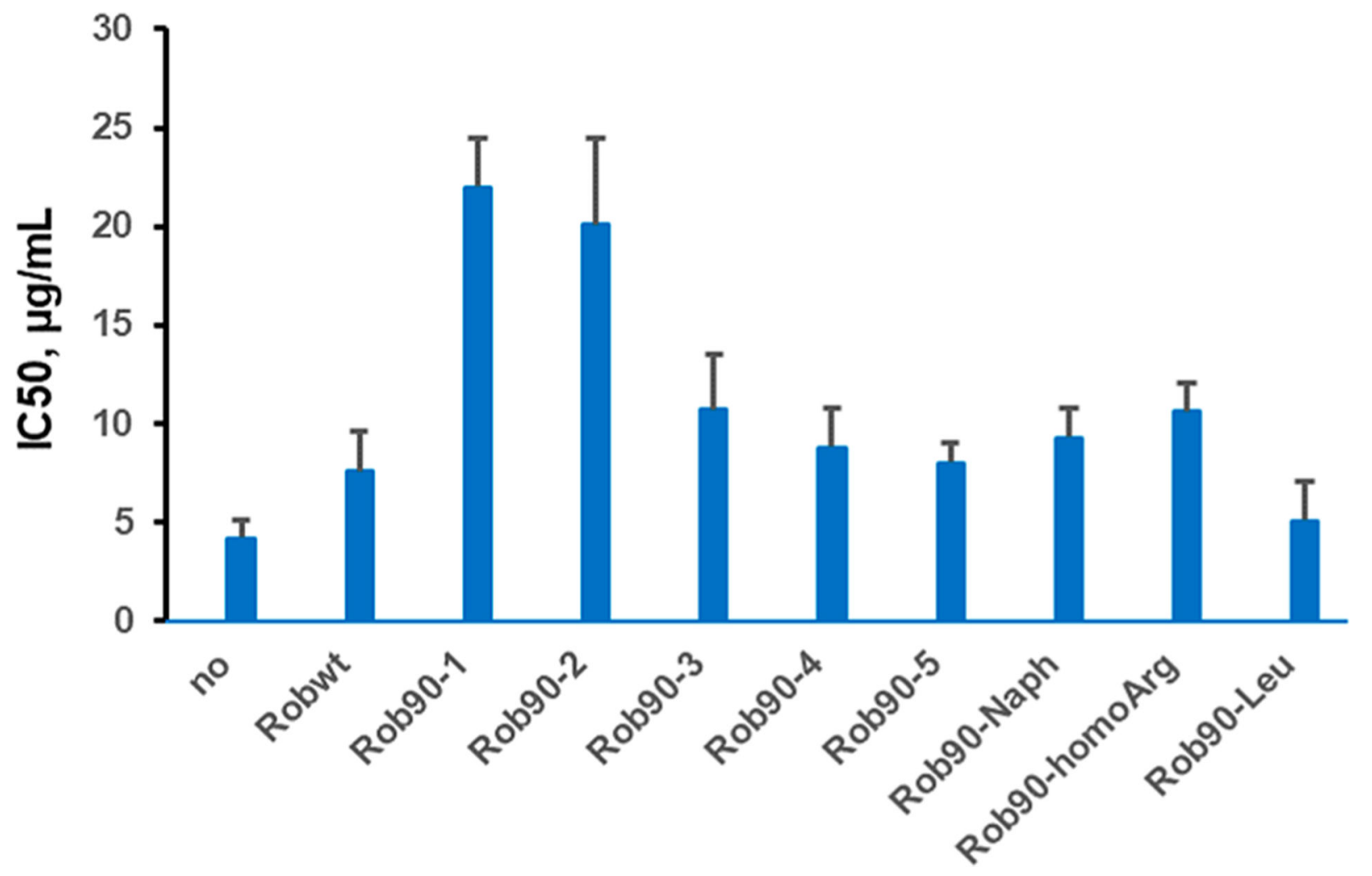

Figure 7.

Resistance of E. coli cultures overexpressing Rob-wt and Rob analogues containing nucleobase (1-5) amino acids or naphthylalanine, homoarginine, and leucine at position 90 to inhibition by $\mathrm{HgCl}_{2}$. For Rob90-1 and Rob90-2 vs Rob-wt, $p<0.05$; for Rob90-3 vs Rob-wt, $p>0.05$. 
Table 1.

Comparison of the Bindings of Different Rob Samples with the Mutations in Position 90 with $m i c F^{a}$

\begin{tabular}{lc}
\hline & DNA binding, $\mathbf{B C}_{\mathbf{5 0}}(\mathbf{n M})$ \\
Rob sample & micF \\
Rob-wt & $63 \pm 11$ \\
Rob90-1 & $39 \pm 2$ \\
Rob90-2 & $38 \pm 5$ \\
Rob90-3 & $41 \pm 4$ \\
Rob90-4 & $80 \pm 10$ \\
Rob90-5 & $56 \pm 12$ \\
Rob90-norArg & $56 \pm 6$ \\
Rob90-homoArg & $47 \pm 8$ \\
\hline
\end{tabular}

For Rob-wt vs Rob90-1, Rob-90-2, Rob-90-3, and Rob90-4, $p<0.05$. For Rob-wt vs Rob90-5, $p>0.05$. 
Table 2.

Comparison of the Binding of Different Rob Samples with Mutations in Position 90 with micFand micFmutB DNA Substrates ${ }^{a}$

\begin{tabular}{lcc}
\hline & \multicolumn{2}{c}{ DNA binding, $\mathbf{B C}_{\mathbf{5 0}}(\mathbf{n M})$} \\
\cline { 2 - 3 } Rob sample & $\boldsymbol{m i c F}$ & micFmutB \\
Rob-wt & $63 \pm 11$ & $83 \pm 3$ \\
Rob90-1 & $39 \pm 2$ & $220 \pm 20$ \\
Rob90-Naph & $34 \pm 6$ & $45 \pm 4$ \\
\hline
\end{tabular}

${ }^{a}$ For Rob-wt (micFvs micFmutB), $p<0.05$. For Rob90-1 (micFvs micFmutB), $p<0.05$. For Rob90-Naph (micFvs micFmutB), $p>0.05$. 
Table 3.

Comparison of the Binding of Different Rob Samples with Mutations in Positions 40 and 90 with $\mathrm{micF}^{2}$

\begin{tabular}{lcc}
\hline & \multicolumn{2}{c}{ DNA binding, $\mathbf{B C}_{\mathbf{5 0}}(\mathbf{n M})$} \\
\cline { 2 - 3 } Rob sample & position 40 & position 90 \\
Rob-wt & $63 \pm 11$ & $63 \pm 11$ \\
Rob-1 & $140 \pm 7$ & $39 \pm 2$ \\
Rob-5 & $104 \pm 13$ & $56 \pm 12$ \\
Rob-Naph & $75 \pm 5$ & $34 \pm 6$ \\
Rob-Phe & $140 \pm 15^{b}$ & $70 \pm 6$ \\
\hline
\end{tabular}

${ }^{a}$ For Rob-1, Rob-5, Rob-Naph, and Rob-Phe (position 40 vs 90), $p<0.01$.

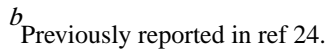

